\title{
OFFICIAL PEDAGOGY, FOREIGN LANGUAGE TEACHING AND LITERACY: A FUNCTIONALIST PERSPECTIVE
}

\author{
Bel ABBEs NedDAR ${ }^{1}$ \\ University of Mostaganem, Algeria
}

\begin{abstract}
The theoretical framework that informs this paper is systemic functional linguistics (Halliday, 1994, Mathiessen, 1995 and Halliday and Mathiessen, 2004). This paper is not meant to be a guide for foreign language teachers on how to teach with a list of prescriptive tips to be adequately followed, but meant to highlight the importance of language teaching as a social functional activity. It stresses the need for a particular type of literacy that helps learners reflect on the ideational content of the educational input, questions beliefs and settled practices of their societies, and dwells on the educational requirement for any country to join the socio-economic revolutionary processes of Globalisation.
\end{abstract}

Key words: Education, pedagogy, foreign language teaching, systemic functional grammar, globalisation.

\section{Introduction}

To start with, the term functional is used here in its Hallidayan sense where language is seen as a semogenic phenomenon. Language is, indeed, a powerful meaning making resource that it is central in the process of socializing the individual. It is, thus central to teaching and learning that take place in our every day experience. It is, as Halliday (1993, p. 94) rightfully points out, " ... the essential condition of knowing, the process by which experience becomes knowledge" (Emphasis in the original). It plays an essential part in our socio-semiotic evolution as human beings.

No matter what our social background is, we all went, in our infancy, through the process of learning before our schooling experience. We are thus all prepared for any experience of official pedagogy. Our ability to learn is natural. What differentiates us is the social environment that we are raised in: our social interactions with our meaning group first (Halliday, 1975) and speech fellowship (Firth, 1957) and finally the wider speech community. As learners, we have all gone, starting from our schooling period, through two parallel types of pedagogy: the official pedagogy which refers to the institutionalized one and the local pedagogy ... that experience of learning implicitly on our own from our social environment. The latter always mediates the former.

Children capacity / speed to learn varies. This variation is not biological; it is in fact due to the social environmental conditions that children are brought up in. Students come to the classroom with their semiotic history. Our role as language teachers is to understand all the socio-semiotic aspects of these learners so that to help them to build the bridges that will give them "freedom to think, open up spaces for the mind to stretch to explore beyond here and now to what it truly means to be human" (Hasan, 2004, p. 70).

This process requires material educational conditions. A government that denies these conditions will necessarily end up with a nation incapable of understanding discrimination and invention (ibid: 43). In fact, underfunding and overcrowding are but two major short -cuts to mediocre education. This point leads us to mention the three key components of 'official pedagogy': curriculum, pedagogy and evaluation. It is necessary to know the place/influence that these components have on transactions between the teachers and the cohort of students with whom they may be dealing. This topic is beyond the scope of this paper.

\footnotetext{
1 E-mail: neddarb@yahoo.co.uk
} 
Lukin (2012) argues that any educational system is iconic of the society in which it is implemented. She goes on saying that authoritarian societies will come up with an educational system that would maintain the existing authoritarian social structures and so on (ibid). In such contexts, what is, then, our responsibility as language teachers?

\section{Teachers' role}

First and foremost, there is a need to understand the nature of language not simply as a set of formal linguistic rules but as a resource for making meaning. We need to know that meaning is not encoded in linguistic forms, 'out there' and 'ready made', so to speak, to be consumed, but it is the outcome of the interface of language and the ecosocial environment. Learners should be well aware that it is a socially collective product derived through a mutually negotiated process (Breen, 1985). As teachers, we should provide learners with the wherewithal to construct, 'on the fly', a bespoke social grammar that not only reflects, to use Hymes' notions, the formally possible and the appropriate, but also the feasible and the performed. Students, in fact, must be aware of how meanings vary according to the use of language and reflect on its role as Halliday $(1989$, p. X) points out:

Language is a political institution: those who are wise in its ways, capable of using it to shape and serve important personal and social goals, will be the ones who are "empowered" (to use a fashionable word): able, that is, not merely to participate effectively in the world, but able also to act upon it, in the sense that they can strive for significant social change.

Internalizing the grammar is not enough for the language teachers. They have to tell their students how this lexicogrammar, in its Hallidayan sense, works so that to make meaning, and how meaning changes when changes at the structural levels are operated. This in fact goes in line with Widdowson's claim that in spite of the essential regulative function grammar has:

It has to be learnt in its regulative function, in association with lexis, as a necessary communicative resource. Over recent years we have seen the restoration of grammar from its temporary exile. But we surely do not want it restored under the old dispensation. We need to enquire into the way it relates to lexis, how it operates as a complement to context in the achievement of pragmatic meaning, how it functions in the regulation of language use. (1992, p. 334)

This cannot be achieved unless, as teachers, we know that grammar, when represented systematically, shows up three distinct network systems: language as reflection (construing human experience), language as action (enacting personal and social relationship), and language as enabling (facilitating the construction of the text). If teachers fail to tell their students that every act of meaning embodies all these metafunctions and show their intrinsic nature to language, learners will always deal with grammar at its formal level devoided of its social- semiotic dimension. Hence, teaching grammar in its traditional form isolated from its functional role, as meaning making resource, is a waste of time, likewise is the introduction of meaning without talking about how the formation of the structure (lexicogrammar) realizes systemic choices. In so doing, teachers will deny their students "the power of reflections of how meanings are transacted in their communities" (Hasan, 2011, p. 374) and capture the reality of language as experienced by its users. Knowing these issues is a precondition for being a teacher of the kind of literacy that Hasan (2011) refers to as 'reflection literacy'.

\section{Types of literacy}

Hasan (ibid) talks about three kinds of literacy: recognition literacy, action literacy and reflection literacy. Recognition literacy presents language as a mere passive means of reflecting pre-existing knowledge without any control of that which it reflects. It is somehow an education, which serves better indoctrination and prepares learners into a framework where they follow orders and conform to the rules of those in power 
(see Chomsky, 2012, p. 3-14). However, language is far more than that. It construes reality and shapes meanings that are socially motivated.

Action literacy is an approach which sees schooling as necessary for providing equal opportunities for learners to develop their discursive competence. For this reason, education has many consequences for life chances in society. It remains one of, if not the best means for social success /promotion in life.

Reflection literacy is a literacy that is meant to produce knowledge. This production starts with the recognition of the semiotic resources and their role in construing ideological discourses that might be challenged. If this kind of literacy is successfully implemented through an appropriate pedagogy, it will produce, within learners, a distrust of what we refer to as 'doxic knowledge', i.e. knowledge whose sole authority is the authority of someone in authority (Hasan, 2011, p. 200). The advantages of this kind of literacy is that it develops within learners an inquisitive mind, a type of knowledge that would enable them to question established beliefs, cultural norms and confirmed discourses, including the educational discursive norms. They would be able hence, to depart from the moulded traditional norms to more organic integration diversities. Literate students in such framework:

might be able to question the wisdom of the short-sighted goals that we have embraced the world over. They might indeed be able to ask what we have lost by gaining control over the environment, while ignoring all notions of self-control, by construing knowledge as a competitive enterprise, while failing to acknowledge the centrality of the over in our very survival as human beings. (Ibid: 200-201)

Indeed, such literacy that turns its back to the established norms and questions them, and if it stands as such will most probably equate the term literate with that of educated and this with that of understanding better our conditions and improving them.

\section{The functional relevance of foreign language teaching}

How does this relate then to the act of foreign language teaching? How can the kind of reflection literacy be implemented in the foreign language classroom? What would then be its functional relevance? One may suggest that why should we, after all, bother ourselves with such a peripheral discipline ... for it is considered as such in most cases ... and claim its relevance? Is not foreign language teaching just a kind of an official educational subject meant to be a sort of 'time filling', keeping students, so to speak, busy?

Over the last two decades and with the emergence of Globalisation, there has been a growing interest/ revival, I would say, in the learning of foreign languages, English in particular. Most of the international education reform movements insisted on establishing English not only as a subject itself, but also and most importantly as a medium/ tool of academic study. This has been intertwined with the capacity to compete internationally and broadening 'students' general and specialised knowledge and build professional expertise in English so that they can take leadership in the international arena' (Taguchi, 2012: 15). Indeed, in many countries English-medium curriculum has been twinned with the efficiency in conducting business and leading international organisations of the $21^{\text {st }}$ century. "We need the English language to enter the global arena. Out of 10 million books published in the world $85 \%$ are in English. The science, all the new developments and information - they are all in English nowadays," asserts the Kazakh president, Nazerbayev (Zhumzhumina, 2013). This interest has to do with the desire of many countries to be part of this ongoing process that involves an increasing local diversity and speedy exchange of commodities and information (Kubota, 2002:13). As such, there is a need to transform social and institutional conventions to adapt to the international demands. For this, human contact through cultural boundaries is a necessity. This raises the discourse of English as a lingua franca/ international language influencing foreign language education. Indeed, the flow of people around the world, the development of the information based economy facilitated by the new information technologies has increased, in this era of globalisation, the need ... to contradict here Pilar and Pavlenko (2009, p. 11) ... for one particular language: English. This has become, 
regardless of what the advocate of linguistic imperialism may think, synonymous with foreign language teaching. As such, all other things being equal, my next discussion will focus mainly on this particular language.

All the educational reforms that took place worldwide promoted the acquisition of the communication means of the West, English in particular. This linguistic choice was believed to enable citizens to express and explain their countries values and points of view to people worldwide. The case of Li Yang Crazy English, in China, and his slogan is a good example: "Conquer English to make China stronger" (Osnos, 2008). This is not the only aim and the sole tendency. This perception of English has not only brought about a phenomenon of English fever, but also endorsed an economic pragmatic view in learning English as an international language (revenues from English language learning reached $\$ 35.5$ billion in 2013 and are expected to raise considerably in 2018). Consequently, it has reinforced ELT practices that aim at preparing learners of English for not only the 'understanding of others' but also for 'being competitive', and here lies the functional relevance for the introduction of English in national curriculums. The aim envisaged is to develop self-expression fostered through learning English for communicative purposes as well as focusing on the 'expressive' mode, along with developing within learners logical thinking necessary in international communication (Kubota, 2002, p. 17). This logical thinking is to be developed through writing and crosscultural understanding. What is questionable is not in fact this choice per se, but the kind of methodology applied to achieve it. The inevitable questions are what kind of literacy is associated with learning English in the educational system? Is there any discrepancy between the political aims and the pedagogical ones? And how English is taught?

Any functional approach to language teaching/learning must take into account the following guiding principles:

- Learning is a semiotically mediated activity.

- Language and content are inseparable.

- Language users make choices based on their linguistic repertoires and these choices are related to the situations they participate in.

- Second language development is an expansion of the meaning making resources.

- Academic language features can be recognized across languages.

- Learning about language by developing a meaning-based metalanguage allows language users to be reflective about the meaning and power of the linguistic choices that others and they themselves make.

- Focused work on analyzing texts allows users to become aware of the meaning and power of language choices.

- Learning is socially distributed and occurs in communities of practice.

(Achugar et al., 2007, p. 12-13)

This can be achieved only through the kind of literacy that Hasan referred to as reflective one and where knowledge of form and knowledge of discourse are treated as varying and variable. There is a necessity in such literacy for the teacher to make learners aware of the choices available to them so that to make meaning and how their choices construe experience and enact social processes. This cannot be realised unless s/he possess a particular knowledge of how to talk about language, a kind of metalanguage that Systemic Functional Linguistics offers, indeed.

Language from a functional systemic perspective is used, as Halliday and Mathiessen 2004 assert, to make sense of reality and carry out interactions with other people.

A key issue in education today is enabling students to participate in learning in such contexts in ways that make new ways of meaning available to all students and that build on linguistic diversity 
as a resource that enriches learning for all. Therefore, pedagogies dealing with this reality need to have a dual focus: promoting academic language development and creating a space to value the linguistic resources students bring with them. (Achugar et al., 2007, p. 9)

However, to go back to the questions that I have raised in the previous lines, there seems to be a negative side about the way English is dealt with in the language classroom. The communicative learning, though it sees meaning as intrinsic to language fails, or should I say, teachers fail to show how this meaning is negotiated, how it is transacted. In other words (in Widdowson's words), there is a need to show how language has been used along a diachronic continuum, so to speak, to serve social functions, and how these uses have been abstracted then semantically encoded (Widdowson, 2004:15). They do not raise learners' awareness to the metafunctions of language and show how they are intrinsic to language itself, i.e. its fundamental property, something that is basic to the evolution of the semantic system. Thus, meaning must not be seen as a single entity realised by the use of language in context, it is a composite of four components: experiential, interpersonal, logical and textual. These are all interwoven in the making of discourse (Halliday and Hasan, 1989). This is the essential nature of a functionalist approach that could make reflection literacy possible. In dealing with meaning in such a perspective, teachers will inevitably address ideological issues and practices allowing their learners to reflect upon the content, looking for ways of construing another reality different from that of the author. The result of this process would make them ready to respond critically to new registers that they encounter in their daily life. They would be less ready neither to align to the cultural assumptions of the text they read nor consume naturally their ideologies.

\section{Conclusions}

It would be hard to see how foreign language teaching could help countries join in the global village if their leaders deny their population the right to question established values by imposing through the educational institutions that they have under their control a monolithic view, their view of the world. We cannot be involved in the ongoing process of globalisation, which by its nature requires openness to the notion of otherness, reflecting/accepting beliefs of others, interacting/cooperating with them while we have been introduced starting from our schooling era to a literacy that recognises only knowledge of he who is in authority and aligns us naturally with the 'official' state discourse. The educational system as it is set in Algeria and in authoritarian countries is a state controlled/contrived system, starting from the management of the school to that of the classroom. The presence of different types of inspectors: administrative and pedagogical is not to ensure a better management, that's what we are left to think, but to ensure the state upper hand on these institutions. Private schools were called for 'order', some closed down, though their management at all levels was simply excellent, just because they did not observe thoroughly the national curriculum ... a pedagogical document imbued with ideological beliefs and practices ... those of the state system. The outcome is such that we have ended up with a mediocre education incapable of providing the country with valuable competencies in all domains on one hand and increasing our ignorance of otherness on the other. We are neither capable of reflecting on our values nor understanding those of other nations. Our schooling institutions are unable to produce knowledge, let alone disseminate it. Countries fall apart, I would argue, when they give the label 'intellectual elite' to people that are incapable of reasoning, thinking and producing knowledge. This happens and happens quite often. After giving the matter a serious thought, it seems at the face of it, that the kind of 'literacy' we are introduced to is that which enables us to read the state instructions and act on the state orders, no less and no more. Between giving me a fish and teaching me how to fish, I would rather go for the latter.

\section{References}

Achugar, M., Schleppegrell, M. \& Oteíza, T. (2007). Engaging teachers in language analysis: A functional linguistics approach to reflective literacy. English Teaching: Practice and Critique, $2 / 6,8-24$. Retrieved from: http://education.waikato.ac.nz/research/files/etpc/2007v6n2art1.pdf 
Breen, M.P. (1985). The Social context for language learning- A neglected situation?, Studies in Second Language Acquisition 7 (2), 135-158.

Chomsky, N. (2012). The Purpose of Education. Language without Frontier. Retrieved from: http://www.youtube.com/watch?v=DdNAUJWJN08

Firth, J.P. (1957). Papers in Linguistics 1934-1951. Oxford: University Press.

Kubota, R. (2002). The Impact of Globalization on language teaching in Japan. In D. Block, and B. Cameron (Eds.) Globalization and Language Teaching. London: Routledge, 47-63.

Halliday. M.A.K. (1975). Learning how to Mean. London: Edward Arnold.

Halliday, M.A.K. (1993). Towards a language-based theory of learning. Linguistics and Education, (5), 93116.

Halliday, M.A.K. (1994). An Introduction to Functional Grammar. Edward Arnold: London.

Halliday, M.A.K. and Hasan, R. (1989). Language, Context and Text: Aspects of Language in a SocialSemiotic Perspective. Oxford: University Press.

Halliday, M. and Mathiessen, C. (2004). An introduction to Functional Grammar, $3^{\text {rd }}$ Ed. Oxford: University Press.

Hasan, R. (2011). Language and Education: Learning and Teaching in Society. Collected Works, vol. 3, Sheffield: Equinox Publishing.

Lukin, A. (2012). Review of Language and Education: Learning and Teaching in Society. Retrieved from: https://vimeo.com/51052605

Mathiessen, C. (1995). Lexicogrammatical Cartography: English Systems. Tokyo: International Language Sciences Publishers.

Osnos, E. Crazy English. 2008. Retrieved from: http://www.newyorker.com/magazine/2008/04/28/crazyenglish

Pillar, I. and Pavlenko, A. (2009). Globalization, multilingualism and gender: Looking into the future. In A. Wei and V. Cook (Eds.). Contemporary Applied Linguistics: Volume 2 Linguistics for the Real World (10-27). London: Continuum International Publishing Group.

Tagushi, N. (2012). Context, Individual Differences and Pragmatic Competence. Bristol: Multilingual Matters.

Widdowson, H.G. (1992). ELT and ELT teachers: Matters arising. ELT Journal, 46 (4), 333-339.

Widdowson, H.G. (2004). Text, Context, Pretext. London: Blackwell Publishing.

Zhumzhumina, A. (2013). Nazarbayev Calls Kazakhstan to learn English, Tengri News. Retrieved from: http://en.tengrinews.kz/edu/Nazarbayev-calls-Kazakhstan-to-learn-English-24393/

Received: 03/02/2016

Accepted: 20/05/2016 